\title{
Screening epidemiological study: blood lead levels in the vicinity of a lead smelter
}

\author{
Z. Safar ${ }^{1} \& \mathrm{~W}$. Lotfi $^{2}$ \\ ${ }^{1}$ Mechanical Engineering Department, Cairo University, Egypt \\ ${ }^{2}$ Faculty of Pharmacy, Al Ahram Canadian University, Egypt
}

\begin{abstract}
The private sector lead smelting industry in Cairo has traditionally been located in a northern suburb, Shoubra el-Kheima. Originally an industrial zone, over time residential blocks have filled in the neighborhood, until now it is one of the country's most densely populated areas. The largest of these smelters is the Awadallah Secondary Lead Smelter, which began operation in 1979, and ceased smelting activities in 2001 as the Government of Egypt (GOE) encouraged smelters to move to new industrial zones and install up-to-date technology to reduce harmful emissions from the smelting process. Since 2001, the smelter facility has been used to refine and manufacture lead products.

Knowing the 'state of the site', however, is only one part of the picture. It is also necessary to ascertain that the smelter imposed no adverse health effects on the people living in proximity to the smelter due to the high levels of lead contamination that exists in the study area. A screening epidemiological study determining blood lead levels - the best available index of body lead load — was conducted to provide further information on the potential impacts of lead contamination in the vicinity of the Awadallah Smelter. This allowed determination of the effect of environmental lead on the blood lead levels of children younger than 7 years of age (the most vulnerable to the harmful effects of lead), on females of reproductive age and on adult males. The study investigated the relationship between the blood lead levels of the target population with lead contamination of the indoor environment-household dust, drinking water, and interior paint.

It was found that the outdoor environment, especially lead contamination of the soil, was the primary cause of elevated blood lead levels in residents. The lead levels of the test group varied from one zone to another, depending on soil lead levels. Another study was done three years after shutting down the smelter and cleaning a children's school situated in the study area, it was found that the blood lead level for most of the children in the school was within the allowable limit.
\end{abstract}




\section{Introduction}

Few secondary lead smelters of old battery-recycling plants are still operating in Cairo and act as point sources of hazardous environmental pollution [1]. The smelters are located in densely populated districts of mixed industrial and residential entities and as such pose a great threat to the community [2]. Environmental injustice is quite evident due to the low socio-economic status of the majority of the populace. Anthropogenic heavy metals are known toxicants, either in their elemental forms or their chemically combined forms. Large amounts of these heavy metals reach the soil by air dispersion and can dangerously accumulate on the surface.

The degree of lead absorbed depends not only on the chemical state of the lead but also on the physical state. Particle size plays a vital role on the fate of the ingested lead; if the particles of the insoluble lead minerals are large, they will be conveyed from stomach to intestines in their original forms but if the particles are small and soluble, they will be readily absorbed [3]. People living close to lead smelters suffer from the hazardous effects of both sizes due to the smelter's emission of the fine particles of reactive lead oxide phases. Once absorbed by the body, the lead is taken by the blood stream and directed to soft tissues. After sometime it will accumulate progressively in the bones due to its resemblance to calcium size-wise the ionic radius of $\mathrm{Pb} 2+$ and $\mathrm{Ca} 2+$ are almost equal $\}$ [4]. Lead's adverse health effects are numerous [5] and are exhibited primarily in the blood forming and nerve tissues. In blood, by inhibiting the enzymes responsible for the biosynthesis of heme. Whereas lead's invasion of the central and peripheral nerve cells is governed by the amount of blood lead level; if BLL is in the $5 \mu \mathrm{g} / \mathrm{dl}$ lead decreases nerve conduction velocity while higher values are associated with the degeneration of the nerve cell itself $[2,6]$. The contribution of lead to other health problems is manifested in growth impairments, auditory pathway and kidney function deterioration [7] to name a few.

Reported Egyptian epidemiological studies on children are critical to the assessment of lead risks, particularly because some children are victims of chronic exposure to lead in Shoubra el-Kheima. A previous investigation of blood-lead levels estimated that the mean blood level for children living in that area was between 10-39 $\mu \mathrm{g} / \mathrm{dl}$ compared with blood lead levels $<10 \mu \mathrm{g} / \mathrm{dl}$ for children living in Dokki, a residential suburb on the west bank of the Nile, which was used as a control group [8]. Salem et al [9], focused on neurobehavioral abilities of the children exposed to environmental pollution in the same study area, and concluded that there was a marked decrease in I.Q. intelligence quotient, scores when compared to the control group, from a non-industrial district.

\section{Objectives}

The purpose of this investigation is to measure BLL of the residents in the contaminated study area, since lead level in blood has consistently been used as 
an indicator of exposure to lead [5]. This is to help elucidate the effect of environmental pollution from various sources of lead exposure to their body lead load. It was important to determine the degree of indoor lead contamination by analyzing the lead concentrations in household-dust, drinking water and interior paint. The relationship between site contamination and BLL is performed in this study for the first time in Egypt.

This screening epidemiological study aims at establishing the relationship between outdoor lead levels of the air, soil, dust and indoor levels of contamination with the blood lead levels of the residents.

\section{Methodology of work}

The study area was confined to a circle of $1 \sim \mathrm{km}$ radius surrounding the Awadallah Smelter with the smelter's stack at the center. More than 300 dust and soil samples were collected and analyzed for lead contamination during four separate rounds of sampling. Figure 1 identifies the target area by delineating the concentration contours of soil and dust lead pollution [ ].

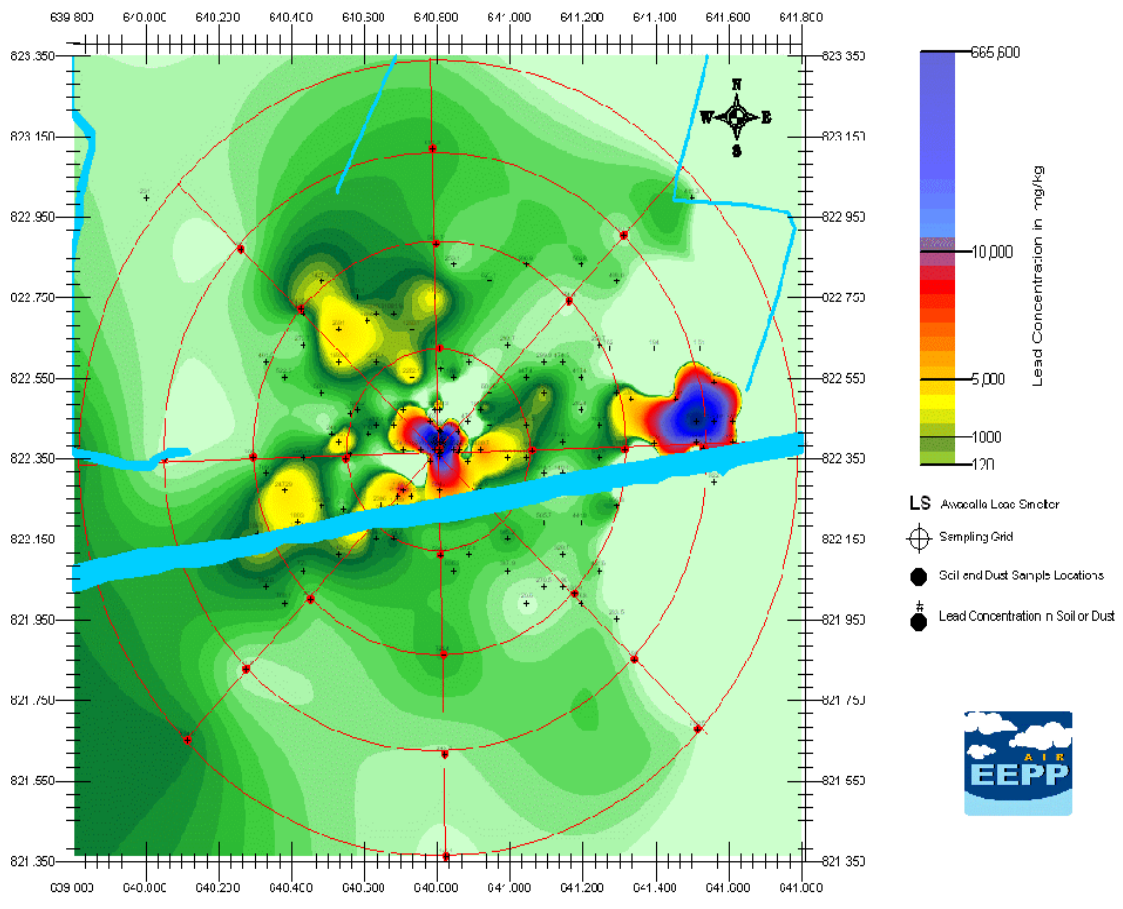

Figure 1: $\quad$ The study area - lead concentration contours for soil and dust.

The area in question was then divided into zones that were designated as Operational Units (OUs), fig. 2, which in turn, correspond to various lead 
concentrations in soil and dust. A cross-sectional analytical survey was carried out to determine the body load of lead among population subgroups in this area.

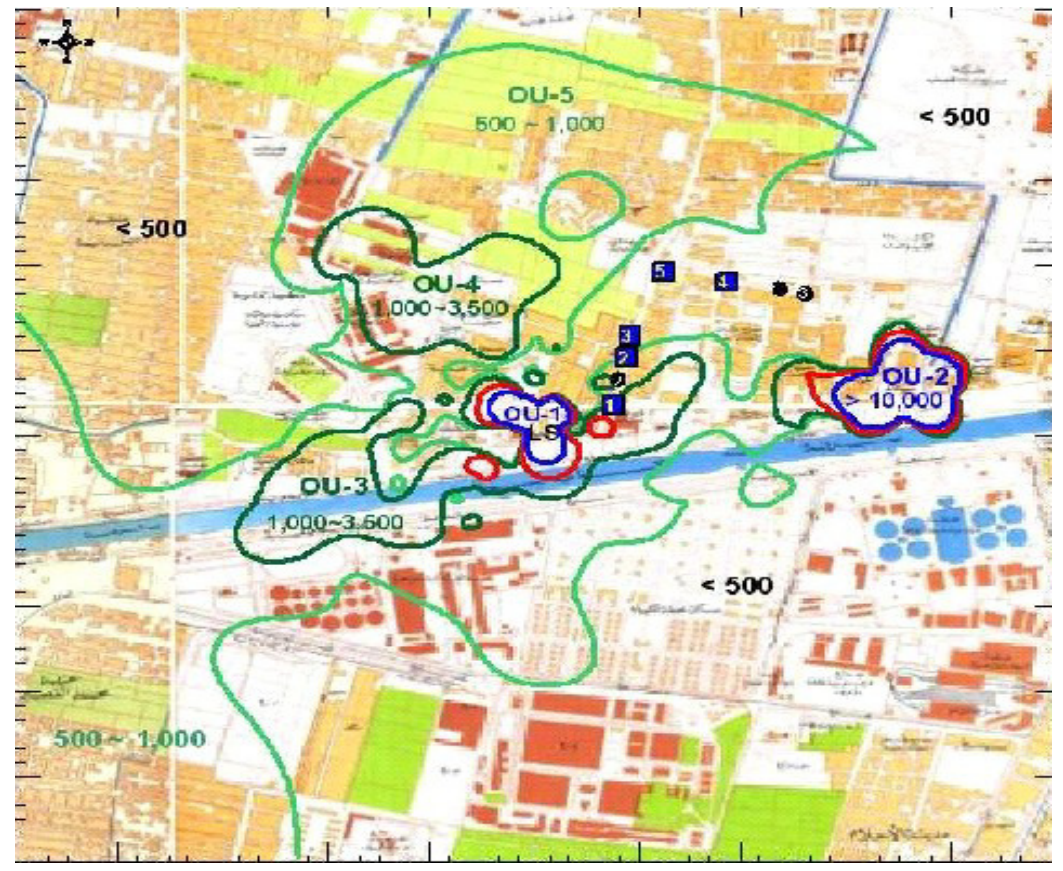

Figure 2: The designation of the zones into Operational Units.

The study concentrated on children from 0-84 months of age and on males and females between 15-49 years of age. A total of 299 blood samples were taken from 134 children younger than 7 years of age, from 88 females of childbearing age, and from 77 males aged 15-49 years. The breakdown of samples taken by OU is shown in table 1 .

Table 1: $\quad$ Blood samples taken by Operational Unit.

\begin{tabular}{|r|r|r|r|r|}
\hline \multirow{2}{*}{$\begin{array}{r}\text { Operational } \\
\text { Unit }\end{array}$} & Male & Female & Children & Total \\
\cline { 2 - 5 } & 8 & 16 & 25 & 49 \\
\hline OU 1 & 11 & 11 & 17 & 39 \\
\hline OU 2 & 17 & 15 & 23 & 55 \\
\hline OU 3 & 9 & 12 & 18 & 39 \\
\hline OU 4 & 32 & 34 & 51 & 117 \\
\hline OU 5 & 77 & 88 & 134 & 299 \\
\hline Total & & & & \\
\hline
\end{tabular}


All of the blood samples were collected from families residing in a total of 82 homes. Eighty-two of the females included in the study were mothers. One hundred and twenty of the 134 children included in the study belonged to these mothers. Whenever possible, one block was chosen from each street in each O.U. From each residential block one flat was targeted. The centralized location of the smelter in residential areas limited the availability of residential blocks in an O.U. difficult, and due to this limitation in the sampling process, sometimes more than one residential block in the same street was targeted. The study population was distributed along the boundaries of the OUs and the outdoor lead contamination levels found in the dust and soil samples.

Ethical approval was obtained from the Ethics Committee at the Ministry of Health and Population before starting the screening survey. All families were asked to sign an informed consent and to assist a researcher in completing a questionnaire. Questions revealed factors that could help determine severity of exposure, socioeconomic status, and personal data.

Household environmental conditions were also considered as they could contribute to the blood lead levels that were found in the target area residents. These include: a) in-house drinking water b) interior paint c) household dust and d) personal habits and behavior.

\section{Experimental}

Venous blood samples were collected from each study subject using a heparinized vacutainer. Determination of blood lead levels was made using standard analytical methods. Quality control of the samples was made by dividing one out of each 12 samples into two different test tubes and giving them different code numbers.

Environmental samples from the interior of 82 flats were collected. These included a tap water sample taken immediately on opening the faucet, a wipe sample for household dust from the room where the family watched TV (and spent most of their time), and a paint sample from non-intact paint (if any) on the walls of the TV room. These were analyzed, and personal habits examined through use of the pre-tested questionnaire that addressed appropriate areas of behaviors and family life.

\subsection{Data collection}

University graduate social workers were trained as data collectors to use the pretested questionnaire, and were accompanied by a field supervisor who ensured that the questionnaires were completed accurately. Data entry was into an Access and Excel (software) database. Entered data was checked twice: once by the entry person, and again by the principal investigator. The data was analyzed using SPSS 11.0 and STATA 8.0 software. A total of 311 blood samples were collected from 299 subjects. Blind duplicate samples were collected from 12 individuals as a quality control/quality assurance measure. 
Results of statistical analysis of the duplicate samples showed only minor differences between the results. The percentage error was between $2-5 \%$.

\subsection{Instrumentation}

The apparatus used for the blood samples was an atomic absorption spectrometer, Perkin Elmer Analyst 100, with background correction deuterium arc lamp. The auto sampler was Perkins Elmer AS 800 and the graphite furnace brand was HGA 850.

The indoor dust wipes, paint chips and tap-water samples were analyzed using a Perkin Elmer Analyst 800 atomic absorption spectrometer with Zeeman background effect. The auto sampler was a GBC 908 type.

\subsection{Reagents and standards}

For the blood analysis $0.1 \% \mathrm{v} / \mathrm{v}$ Triton X-100 [octyl phenoxy polyethoxyethanol] and $0.8 \mathrm{M} 5 \% \mathrm{v} / \mathrm{v}$ analytical grade nitric acid and dibasic ammonium phosphate as matrix modifier. For the dust wipes, 1:1 lead free reagent grade nitric acid: water and $30 \%$ hydrogen peroxide were used. Lead nitrate analytical grade was used throughout the analytical determinations.

\subsection{Sample collection and preparation}

\subsubsection{Blood samples}

Blood samples were attained by venipuncture and not by the finger-stick method since blood taken by the latter method has a higher percent of contamination [10]. Latex sterilized gloves were used to take each sample. The blood sample was put into a vacutainer containing lithium heparin as an anticoagulant and placed in an icebox for consequent analysis. The analytical techniques used for the preparation and analysis of the blood samples were those proposed by Yee et al [11] which takes into account other relevant techniques and standard operating procedures $[12,13]$. As for the analysis itself it is based on deproteinizing blood with $0.8 \mathrm{M} 5 \% \mathrm{v} / \mathrm{v}$ analytical grade nitric acid and $0.1 \% \mathrm{v} / \mathrm{v}$ Triton X-100 [octyl phenoxy polyethoxyethanol]. The matrix modifier, dibasic ammonium phosphate, stabilizes the lead in blood and aids in the removal of the blood matrix. This method was chosen for many reasons, some of which are its high percentage recovery-between $97.7-105.6 \%$ - and its high sensitivity and precision.

\subsubsection{Dust wipes}

Whereas for the wipe dust samples, the sampling scheme implemented is the one indicated for floors, walls as well as window sills for measuring lead dust in houses [14].

The process is based on choosing a brand of wipes that do not contain lanolin or aloe - the former because it increases difficulties in lab preparation while the latter gives higher lead content. 
For floors, a square template of $1 \mathrm{ft}$ sq dimension is placed in the designated area and with clean plastic powder-less gloves donned, the technician, with the wipes folded properly, forms "S"-like motions on the surface in order to ensure that the dust has been totally removed. For windowsills, no template is available and the sampling technician measures the area after removing the dust with the wipes. A plastic measuring tape is used for this purpose. Finally, the wipe is placed in a plastic centrifuge tube covered with Para film and labeled, then placed in a zip lock baggy and put in an ice container and sent to the lab $[15,16]$.

The standard analytical procedure used is the ASTM: E $1644-98$ method [17] which is based the NIOSH 7082 Method [18] and covers acid digestion of the settled dust samples collected using wipes. Twenty-five $\mathrm{ml}$ of 1:1 lead free reagent grade nitric acid: water is added to the beaker, gently heated while being covered with a watch glass to $100^{\circ} \mathrm{C}$ \{on hot plate at $140^{\circ} \mathrm{C}$ \} and then refluxed for 15 minutes without boiling. The wipe sample was then placed, with the help of a glass rod, into the digestion mixture for extraction. When the sample cooled, $10 \mathrm{ml}$ of concentrated nitric acid was added and refluxed for half an hour. When the sampled cooled and evaporated to $10 \mathrm{ml}, 5 \mathrm{ml}$ of distilled water and an equal amount of hydrogen peroxide $30 \%$ were added. At this step excessive effervescence occurs \{placed watch glass\}, the digestate was consequently heated until the effervescence subsides and room temperature is reached. The digestate and the residues were quantitatively transferred into a $100 \mathrm{ml}$ volumetric flask, diluted to volume with distilled water. This digestate contains a concentration range of $10 \% \mathrm{HNO} \mathrm{v} / \mathrm{v}$ and the calibration standards were made using also $10 \% \mathrm{HNO}$.

\subsubsection{Paint chips}

Dust wipe sampling must always be performed prior to paint chip sampling in order to minimize cross contamination. Deteriorated paint is the targeted paint since it is more hazardous than intact paint.

The collection of the paint chips was performed following strict the measures outlined in the HUD Guidelines (US Department of Housing and Urban Development) [19].

The sample preparation method for flame atomic absorption is the EPA \# 3050 B [20]. Analysis was carried out according to the NIOSH \# 7082 method using FLAAS [18]. Quantitative wet aching analysis techniques comprise the following steps; Lead- free, reagent- grade concentrated nitric acid is added to the sample along with hydrogen peroxide $30 \%(\mathrm{w} / \mathrm{w})$. The mixture is then heated on a hot plate [beaker covered with watch glass] at $140^{\circ} \mathrm{C}$ until the volume is reduced to $0.5 \mathrm{ml}$, this process is repeated twice. When sample is dry, $\sim 5.0 \mathrm{ml}$ of $10 \%$ nitric acid is added and then the solution is allowed again to evaporate to dryness.

When the mixture cools down, the residue is dissolved in $1.0 \mathrm{ml}$ concentrated nitric acid and the solution is consequently transferred to a $10 \mathrm{ml}$ volumetric flask and diluted to the mark using de-ionized water. A series of working standards covering the ranges 0.25 to $20 \mu \mathrm{g} / \mathrm{ml} \mathrm{Pb}$ were made and stored in polyethylene bottles using the $10 \%$ nitric acid. 
The spectrometer was adjusted so that the wavelength used for absorption was $283.3 \mathrm{~nm}$. The standards, samples and blanks were aspirated and the absorption readings were thus recorded at that designated wavelength.

\subsubsection{Household tap water}

For the household tap water screening that was introduced in this study the samples were obtained from the kitchen faucet so as to be the representative sample of what can be consumed during the day at home. It contained water that had been in contact with the tap and lateral pipes overnight.

For the collection, preservation and sample handling, EPA methods were followed [21]. The preparative and analytical techniques implemented were also according to the EPA standards, [22, 23].

\section{Results and discussion}

\subsection{Population Assessed}

About the same number of families was selected in each OU, except for OU 5, where the population is the largest, and the number of selected families was proportionally larger as well. The mean age of recruited children was 3.9 years. Some children were younger than a year, but none were older than 7 years of age. There was an average of 2.85 children per family, and family size ranged up to as many as seven children. However, only a maximum of two children from each family were recruited for the study.

Table 2: $\quad$ Socio-economic status of study families.

\begin{tabular}{|c|c|c|c|}
\hline & & Father & Mother \\
\hline \multirow{3}{*}{ Education } & Illiterate & $33.3 \%$ & $54.8 \%$ \\
\hline & Pre-university & $54.8 \%$ & $38.1 \%$ \\
\hline & $\begin{array}{l}\text { University } \\
\text { Degree }\end{array}$ & $11.9 \%$ & $7.1 \%$ \\
\hline \multirow{3}{*}{ Occupation } & Unemployed & $4.8 \%$ & $90.4 \%$ \\
\hline & Worker & $62.7 \%$ & $4.8 \%$ \\
\hline & Professional & $28.5 \%$ & $4.8 \%$ \\
\hline \multirow{3}{*}{$\begin{array}{l}\text { Family } \\
\text { Income }\end{array}$} & $<$ LE400/month & \multicolumn{2}{|r|}{$54.8 \%$} \\
\hline & $\begin{array}{l}\text { LE400- } \\
\text { 1000/month }\end{array}$ & \multicolumn{2}{|r|}{$35.7 \%$} \\
\hline & $>$ LE1000/month & \multicolumn{2}{|r|}{$9.5 \%$} \\
\hline
\end{tabular}

The general level of both education and profession was low for men and women. A third of the men were illiterate, as were more than half the women. Most of the males are non-professional workers, as were half the females who work. Most of the women, however, were housewives. None of the men or 
women included in the survey was working in a job related to lead. More than half of the families $(54.8 \%)$ had a very low income.

The socio-economic status of the 82 families is shown in table 2 .

The children recruited for the study were equally male and female. Most$72.6 \%$ - were reported to play on the streets on a regular basis. Most (68.9\%) spent more than an hour a day in such play.

More than half of the children were reported to put their hands into their mouth, a practice that can increase their risk of exposure to dust contaminated with lead. Fifty percent of children were reported to eat unwashed vegetables and fruits. Eating food with dirty hands and the use of medicines that could contain lead (Kohl) were reported in 41.9 and $40.3 \%$ of the children, respectively. Regular or occasional eating of non-food material (pica), which could be an important source of lead exposure among children, was reported in $25.8 \%$ of the study group.

\subsection{Blood lead level and blood hemoglobin}

Venipuncture was used to collect blood samples from each subject. This method was used as opposed to the finger-stick method to increase reliability. It is important analytically that $3 \mathrm{ml}$ of blood is need for analysis. This allows the analysis to be repeated if necessary.

Both BLL and blood hemoglobin (Hgb) tests were carried out. The international standard for lead in blood is that no more than $5 \%$ of children in the study population would have blood lead levels of $10 \mu \mathrm{g} / \mathrm{dl}$ or more (US EPA, 1994). Hemoglobin is contained in red blood cells and carries oxygen in the blood. Both high and low hemoglobin counts indicate defects in the balance of red blood cells in the blood, and may indicate disease. Lower than normal hemoglobin counts may indicate anemia, especially in children. Normal values for men range between $13.8-17.2 \mathrm{gm} / \mathrm{dl}$, and between $12.1-15.1 \mathrm{gm} / \mathrm{dl}$ for women. For children up to 7 years old, the Hgb should not be below $12.5 \mathrm{gm} / \mathrm{dl}$, and less than $10.5 \mathrm{gm} / \mathrm{dl}$ is anemic.

Results of the blood lead level and blood hemoglobin testing are shown for each OU in table 3.

Table 3: $\quad$ Blood lead level and blood hemoglobin test results by OU.

\begin{tabular}{|l|c|c|c|c|c|c|}
\hline \multirow{2}{*}{$\begin{array}{c}\text { Operational } \\
\text { Unit }\end{array}$} & \multicolumn{3}{|c|}{ BLL $(\mu \mathrm{g} / \mathrm{dl})$} & \multicolumn{3}{c|}{ Hgb $(\mathrm{gm} / \mathrm{dl})$} \\
\cline { 2 - 7 } & Min & Max & Mean & Min & Max & Mean \\
\hline OU 1 & 4.1 & 35.3 & 22.51 & 9.8 & 16.0 & 12.46 \\
\hline OU 2 & 1.98 & 18.79 & 8.88 & 8 & 16.4 & 12.88 \\
\hline OU 3 & 5.69 & 25.75 & 14.23 & 9.7 & 17 & 13.32 \\
\hline OU 4 & 2.63 & 40.75 & 18.89 & 10. & 15.8 & 12.33 \\
\hline OU 5 & 2.1 & 23.5 & 10.76 & 8.5 & 16.1 & 12.56 \\
\hline
\end{tabular}


Results revealed a difference between the BLL and Hgb in males, females, and children. Table 4 shows the mean BLL and Hgb for different groups in the OUs.

Table 4: $\quad$ Mean blood lead and blood hemoglobin levels in men, women, and children by OU.

\begin{tabular}{|c|c|c|c|c|c|c|}
\hline \multirow{2}{*}{ OU } & \multicolumn{2}{|c|}{ Males } & \multicolumn{2}{c|}{ Females } & \multicolumn{2}{c|}{ Children } \\
\cline { 2 - 7 } & BLL & Hgb & BLL & Hgb & BLL & Hgb \\
\hline OU 1 & 27.88 & 14.8 & 22.71 & 13.01 & 20.53 & 11.96 \\
\hline OU 2 & 9.55 & 14.66 & 7.81 & 12.46 & 9.13 & 11.99 \\
\hline OU 3 & 17.35 & 15.59 & 15.24 & 12.19 & 11.07 & 12.4 \\
\hline OU 4 & 25.96 & 13.93 & 16.61 & 12.17 & 16.75 & 11.6 \\
\hline OU 5 & 10.81 & 14.12 & 9.36 & 11.9 & 11.68 & 12.07 \\
\hline
\end{tabular}

The percentage of residents in each of the OUs with BLL that exceeded the allowable standard of $10 \mu \mathrm{g} / \mathrm{dl}$ is shown in table 5 .

Table 5: $\quad$ Percent of population with BLL $>10 \mu \mathrm{g} / \mathrm{dl}$, by OU.

\begin{tabular}{|c|c|c|c|}
\hline OU & Male & Female & Children \\
\hline OU 1 & 100 & 100 & 84 \\
\hline OU 2 & 45 & 27.3 & 29.4 \\
\hline OU 3 & 82.4 & 46.6 & 45.5 \\
\hline OU 4 & 100 & 100 & 69.2 \\
\hline OU 5 & 38 & 26.4 & 48 \\
\hline
\end{tabular}

OU 1, the most polluted area in the first 50 meters from the Awadallah Smelter, has both the greatest soil and dust contamination and the highest mean value of blood lead levels. This area has the most hazardous effects, especially on children, since $84 \%$ of children had BLL above the standard $(10 \mu \mathrm{g} / \mathrm{dl})$ and have low levels of hemoglobin, bordering on anemia that could be either a manifestation of lead toxicity or nutritional in nature or both.

OU 2, with the next-to-highest contamination of soil and dust has the lowest mean BLL. Only about $30 \%$ of the children had BLL above the $10 \mu \mathrm{g} / \mathrm{dl}$ standard. This is probably due to the fact that this is a new residential area and all members of the test group had occupied their homes for only 2 months. If they continue to live in these flats, and if there is no change in environmental conditions, it is expected that, over a limited period, their blood lead levels will rise to reflect the conditions around them.

It appears that the hot spots in OU 3-where concentrations are found between 3,500-10,000 $\mathrm{mg} / \mathrm{kg}$ - have less effect on the BLL of the residents, since these hot spots are limited and not accessible to residents. They are located 
south of residential buildings. About $45 \%$ of children residing in OU 3 have BLLs higher than the standard limit.

Residents of OU 4, which is northwest of the Awadallah Smelter, have the second highest BLL of $18.89 \mathrm{mg} / \mathrm{dl}$. Nearly $70 \%$ of children have BLLs higher than $10 \mu \mathrm{g} / \mathrm{dl}$. The buildings in this area are old and have been exposed to lead contamination for a long time. In addition, many of these OU residents live downwind from both the Delta Steel Company and a tannery.

OU 5 residents-where dust and soil contamination is less than 1000 $\mathrm{mg} / \mathrm{kg}$ - have average BLL of $10.76 \mathrm{mg} / \mathrm{dl}$, as shown in table 6 . BLLs in children, however, were very high: $48 \%$ of children had levels in excess of the standard. This may be due to continued exposure in ambient air from smelters that are still operating illegally under cover of darkness.

These results suggest that the BLL in humans is proportional to the environmental soil lead contamination for people residing in the contaminated area over a long period. The soil lead concentration is the predominant factor in the BLL; it is a greater influence than other environmental factors inside the house. It is clear that residents in the study area were not aware of the precautions they should be taking to avoid exposure to the hazards of lead contamination. Public education programs about how to minimize the hazardous effects of exposure to lead are essential.

\subsection{Household environmental conditions}

More than half of the families had occupied their flats for more than 5 years before the date of interview. This means they had been exposed to the risk of lead, if any, for a long time. However, in OU 2, participating families were living in new flats built by the government adjacent to the El-Mahy Smelter; they had been in residence for only 2 months, meaning they had not been exposed to the hazardous environment for very long.

Most of the flats were painted (88.1\%), although the paint was not intact in $46 \%$ of those flats, exposing inhabitants - especially children - to the risk of leaded paint. (See appendix 3 for lead paint test results.) Very few families owned electric vacuum cleaners (11.9\%), 69\% left windows open, and $71.4 \%$ wore outdoor shoes inside their flats. Sixty-four percent of the flats were dusty. Nineteen percent of the families cooked food in clay pots that could contain lead, and $40.5 \%$ used food from cans that could contain lead solders. However, this exposure to lead seemed of less significance than exposure to household dust.

Environmental conditions studied in the homes included concentrations of lead in the dust taken from floors and windowsills, and in the drinking water. Some lead was found in drinking water samples (appendix 3). Table 6 shows results for lead concentrations in dust samples.

The US EPA has defined the maximum limit of lead concentration in household dust from the floor as $40 \mu \mathrm{g} / \mathrm{ft}^{2}$; in windowsill dust, the maximum limit is $250 \mu \mathrm{g} / \mathrm{ft}^{2}$. The percentages of homes that have windowsill and floor lead dust exceeding the limit are shown in table 7. 
These figures confirm that as the lead concentration in the soil and ambient air decreases, the lead dust on household windowsills and floors decreases as well.

Table 6: $\quad$ Average lead level in floor and windowsill dust by OU.

\begin{tabular}{|c|c|c|c|c|c|c|}
\hline \multirow{2}{*}{ OU } & \multicolumn{3}{|c|}{ Floor Lead Dust Level } & \multicolumn{3}{c|}{$\begin{array}{c}\text { Windowsill Lead Dust Level } \\
\mu \mathrm{g} / \mathrm{ft}^{2}\end{array}$} \\
\hline & Min & Max & Mean & Min & Max & Mean \\
\hline OU 1 & 16.4 & 76.9 & 38.5 & 1.5 & 1879 & 326.5 \\
\hline OU 2 & 30.3 & 204.3 & 73.1 & 52.7 & 92,326 & 9194.3 \\
\hline OU 3 & 6.6 & 159.5 & 50.35 & 12.7 & 3768.4 & 788.7 \\
\hline OU 4 & 1.9 & 204 & 187.6 & 0 & 1583.2 & 275.2 \\
\hline OU 5 & 4.0 & 38.2 & 24.5 & 0.02 & 2875.2 & 297.1 \\
\hline
\end{tabular}

Table 7: Homes with floor and windowsill dust exceeding US EPA Maximum Lead Limits.

\begin{tabular}{|l|c|c|}
\hline OU & $\begin{array}{c}\text { Percent with Floor Dust } \\
\text { Exceeding Limits }\end{array}$ & $\begin{array}{c}\text { Percent with Windowsill } \\
\text { Dust Exceeding Limits }\end{array}$ \\
\hline OU 1 & 36 & 43.75 \\
\hline OU 2 & 72 & 54.54 \\
\hline OU 3 & 23 & 58.33 \\
\hline OU 4 & 20 & 22 \\
\hline OU 5 & 9 & 20 \\
\hline
\end{tabular}

\subsection{The smelter's human health survey}

The design of this study was based on the previous site characterization study, in which soil concentrations of lead in the study area were determined and the area divided into five OUs depending on lead contamination levels. Those OUs were used to define the study population for this survey, to investigate whether there was a relationship between lead contamination levels in soil and dust and blood lead levels in neighborhood residents.

Families in 82 flats were recruited for the study and blood samples and data were collected from them. The blood samples were tested for lead level and for hemoglobin level. In addition, some fingernail and breast milk samples were taken.

Household environmental conditions were tested, including taking wipe samples of dust from floors and windowsills, samples of the kitchen tap water, and completing a questionnaire with each family that addressed individual behaviors. 
High levels of lead were found in dust from floors and windowsills of some flats-more than 10 times higher than standard levels in some areas. Drinking water showed no evidence of lead. Only one paint sample of 35 tested had a lead level about $600 \mathrm{ppm}$.

It was found that that outside environment, especially lead contamination of the soil, was the primary cause of elevated BLL in residents. The BLL of the test group varied from one zone to another, depending on the soil lead levels. The only exception was for OU 2, where residents had moved into new flats only 2 months before testing.

- $\quad$ OU 1 - an area with a radius of $50 \mathrm{~m}$ around the Awadallah Smelter. This area had the highest levels of lead contamination in soil. It also had the highest risk to health of all the OUs. All men, all women, and $84 \%$ of children younger than 7 years of age have BLLs higher than $10 \mu \mathrm{g} / \mathrm{dl}$. The mean BLL in this area was $22.5 \mu \mathrm{g} / \mathrm{dl}$.

- OU 2-areas near the El-Mahy Lead Smelter where new residential blocks have only recently been opened. These new tenants are not yet affected by the level of contamination in the soil, and only $45 \%$ of men, $27 \%$ of women, and $29 \%$ of children have BLL higher than $10 \mu \mathrm{g} / \mathrm{dl}$. The mean BLL in this area was $8.88 \mu \mathrm{g} / \mathrm{dl}$. Note that it is possible there are other residents in the area of ElMahy that do have more elevated BLL due to longer exposure.

- OU 3-this area extends from southeast to southwest of the Awadallah Smelter and north to the Ismailia Canal. Overall soil contamination is less than in OU 1 or OU 2, but there are some "hot spots" with soil lead concentrations above $3500 \mathrm{mg} / \mathrm{kg}$. The hot spots in this area are quite limited, not accessible to residents, and they are located to the south (downwind) of the residential blocks. The mean BLL of residents is $14.23 \mu \mathrm{g} / \mathrm{dl}$ with $82 \%$ of men, $46 \%$ of women, and $45 \%$ of children having BLL that exceeds the allowable maximum limit

- $\quad$ OU 4-this area is northwest of the Awadallah Smelter but downwind of the Delta Steel Company, which is probably the main reason the study found high concentrations of lead in the dust on floors and windowsills in this area. The mean BLL is $18.89 \mu \mathrm{g} / \mathrm{dl}$. All men and all women residing in this area and $69 \%$ of children have BLL greater than $10 \mu \mathrm{g} / \mathrm{dl}$.

- OU 5-this area has soil lead concentrations of less than $1000 \mathrm{mg} / \mathrm{kg}$. Mean BLL is $10.76 \mu \mathrm{g} / \mathrm{dl}$, with $38 \%$ of men, $26 \%$ of women and $48 \%$ of children having BLL above $10 \mu \mathrm{g} / \mathrm{dl}$.

\subsection{Blood lead study after remediation}

After the smelter stopped functioning, the owner remediated the site by replacing the contaminated soil. During the coAfter the smelter stopped functioning, the owner remediated the site by replacing the contaminated soil. During the course of this study, it was evident that children attending schools located in the target area were exposed to detrimental effects due to the direct adherence of the premises to the smelter. A non-governmental organization (NGO) under the supervision of the National Council for Women (NCW) assisted in remediating the schools and renovating them. The schools were painted with non-leaded paint, cleaned with a HEPA vacuum and the soil and dust in the playgrounds 
removed. After a sufficient period of time, approximately one year, a blood lead screening survey aimed at monitoring if any effects due to lead intervention can be predicted. Lead intervention in polluted sites has played a vital role in decreasing BLL in children [24]. School children were the subjects of the followup screening study which also included female teachers. In this round of BLL screening, two schools were chosen. A total number of 141 samples were collected from children between the ages of 6-8 years and female teachers between 25-49 years of age. Table 8 indicates the number of subjects and their age groups.

Table 8: $\quad$ School children and teachers according to age group.

\begin{tabular}{|l|c|c|c|c|c|c|c|c|}
\hline SCHOOL & \multicolumn{3}{|c|}{ Total Boys } & \multicolumn{3}{c|}{ Total Girls } & Teachers & Total \\
\hline $\begin{array}{l}\text { A. Shalan } \\
\text { School - } \\
\text { School \#1 }\end{array}$ & $\begin{array}{l}\text { 6 years } \\
\text { of age }\end{array}$ & $\begin{array}{c}7 \text { years } \\
\text { of age }\end{array}$ & $\begin{array}{c}8 \text { years } \\
\text { of age }\end{array}$ & $\begin{array}{c}6 \text { years } \\
\text { of age }\end{array}$ & $\begin{array}{c}7 \text { years } \\
\text { of age }\end{array}$ & $\begin{array}{c}\text { Between } \\
8-11\end{array}$ & $\begin{array}{c}25-49 \\
\text { years }\end{array}$ & \\
\hline & 19 & 8 & 3 & 16 & 7 & 3 & 13 & 69 \\
\hline $\begin{array}{l}\text { El Kablat } \\
\text { School- } \\
\text { School \#2 }\end{array}$ & 21 & 9 & 1 & 16 & 9 & 5 & 11 & 72 \\
\hline
\end{tabular}

Results revealed that for school \#1, the percentage of 6 year -old girls with BLL $>10 \mu \mathrm{g} / \mathrm{dl}$ is $6.2 \%$ and those between $5-10 \mu \mathrm{g} / \mathrm{dl}$ is $43.8 \%$ and $50 \%$ were less than $5 \mu \mathrm{g} / \mathrm{dl}$. For 7 year olds the results were better with none exceeding the $10 \mu \mathrm{g} / \mathrm{dl}$ limit and the majority, $85.7 \%$ of the girls, were between the $5-10 \mu \mathrm{g} / \mathrm{dl}$ range. $46 \%$ of the total girls were anemic $<14 \mathrm{~g} / \mathrm{dl}$ hemoglobin.

For boys, the percentage of 6 year- olds with BLL $>10 \mu \mathrm{g} / \mathrm{dl}$ was $5.3 \%$ and for 7 year- old groups it was none. The total number of anemic boys was $83 \%$.

For the female teachers, $77 \%$ of them had BLL>10 $\mu \mathrm{g} / \mathrm{dl}$ and $23 \%$ were anemic.

The results of school \#2 were less favorable, with $18.8 \%$ and $55.5 \%$ of 6 year-old girls and 7 year-old girls respectively, were above the $10 \mu \mathrm{g} / \mathrm{dl}$ threshold. Anemic cases were $37 \%$ of the total number of girls for that school. Whereas the boys were $19 \%$ and $22 \%$ with BLL $>10 \mu \mathrm{g} / \mathrm{dl}$ for the 6 and 7 yearolds respectively, and $84 \%$ with anemic condition. The teachers were $100 \%$ above the threshold and $45 \%$ were anemic.

\section{Conclusion}

Lead is a toxin that has no biological function but causes varied adverse health effects through interference with the proper functioning of body systems. Children less than 7 years of age and fetuses are particularly susceptible to lead toxicity. In this investigation it was confirmed that the target population suffered from higher body burden of lead. It was also evident that outdoor soil and dust contamination are the major exposure factors affecting the residence as the results showed no lead in paint or in drinking water. In spite of the fact that the 
owner of the smelter remediated the site by removal of soil only, and under no specific standards, it was clear that the BLL of the children living in the study area had considerably decreased. This evidence confirms that renovation and remediation had a positive effect on those children.

Also it was clear that the residents are unaware of any means of protection from lead poisoning that they could employ to reduce the risk to themselves and their families from environmental lead in dust, soil, air, food, and water.

\section{Acknowledgements}

This work was supported by the Ministry of State for the Environment. Special thanks are extended to the National Council for Women, NCW, and to the Center for Environmental Monitoring and Occupational Health - Ministry of Health and Population. Environmental samples were analyzed in the laboratories of EGSMA, the Egyptian General Authority for Geological Survey and Mining.

\section{References}

[1] Site Investigation Report; Egyptian Environmental Policy Program (EEPP)/Air Quality Program, Cairo, 2003.

[2] Baseline Human Health Risk Assessment: Awadallah Secondary Lead Smelter; Egyptian Environmental Policy Program-Air Activity (EEPPAir), Cairo, 2004.

[3] Shannon, M. W., Lead (Chapter 57). Clinical Management of Poisoning and Drug Overdose, ed. L.M. Haddad, M.W. Shannon, \& J.F. Winchester, Saunders: Philadelphia, Pennsylvania, pp. 767-780, 1998.

[4] Spiro, T.G. \& Stgliani, W.M., Chemistry of the Environment, Prentice Hall: New Jersey, pp. 445-551, 2003.

[5] Environmental Pollution and Disease: Links Between Exposure and Health Outcomes; USEPA Environmental Indicators Initiative. www.epa.gov/indicators/roe/html/

[6] Case Studies in Environmental Medicine, Lead Toxicity; Agency for Toxic Substances and Disease Registry (ATSDR), U.S. Department of Health and Human Services. www.atsdr.cdc.gov

[7] The Adult Blood Lead Epidemiology and Surveillance Program (ABLES); Centers for Disease Control and Prevention (CDC), U.S. Department of Health and Human services. www.cdc.gov /niosh/ables.html

[8] Koura, A.M., Salem, S.I., El-Mahdy. E.M. \& Orban, H.A., Biochemical indicators of lead exposure in blood and urine of children. Kasr ElAaini Medical Journal, 7(2), pp.55-69, 2001.

[9] Salem, S.I., Mosseilhy, S., Khalifa, A., El- Ashmawy, E., Karam El Din, M. \& Salah, I., Blood lead, delta-aminolevulinic acid dehydratase and neurobehavioral abilities among children exposed to lead pollution. Journal of Arab Child (JAC),11(4), pp. 531-548,2000. 
[10] Childhood Blood Lead Screening: Anniston, Alabama; Agency for Toxic substances and Disease Registry (ATSDR). www.atsdr.cdc.gov /NEWS/annistonreport.html

[11] Yee, Y., Nelson, J.D., \&Jackson, B., Measurement of lead in blood by graphite furnace atomic absorption spectrometry. Journal of Analytical Toxicology, vol. 18, pp.415-418, 1994.

[12] Miller, D.T., Paschal, D.C., Gunter, E.W., Stroud ,P.E. \& D’Angelo, J., Determination of lead in blood using atomic absorption spectrometry with modifier. Analyst, vol. 112, pp. 1701-1704, 1987.

[13] Lead Analysis on Perkin Elmer Model 5100 GFAA Spectrometer, Standard Operating Procedure SOP\#13; U.S. Environmental Protection Agency, Environmental Services Division Laboratory,1994.

[14] Wipe Sampling Lead-Contaminated Dust, HUD Guidelines; U.S. Department of Housing and Urban Development. www.hud.gov/.

[15] Residential Sampling for Lead: Protocols for dust and Soil Sampling; U.S. Environmental Protection Agency. www.epa.gov/

[16] Standard Practice for Field Collection of Settled Dust samples Using Wipe Sampling methods for Lead determination by Atomic Spectrometry Techniques, ASTM: E - 1728; American Society of Testing and Materials. http://webstore.ansi.org/ansidocstore/astm.asp

[17] Standard Practice for Hot Plate Digestion of dust Wipe samples for the determination of Lead, ASTM: E 1644-98; American Society of Testing and Materials. http://webstore.ansi.org/ansidocstore/astm.asp

[18] Lead by Flame AAS: Method 7082, NIOSH Manual of Analytical Methods (NMAM); National Institute of Occupational Safety and Health (NIOSH). www.cdc.gov/niosh

[19] Guidelines for the Evaluation and Control of Lead-based Paint Hazards in Housing; U.S. Department of Housing and Urban Development. www.hud.gov/.

[20] Acid Digestion of Sediments, Sludges and Soils, EPA Method -3050B; U.S. Environmental Protection Agency (USEPA), SW-846 On-Line. www.epa.gov/epaoswer/hazwaste/test/main.htm

[21] Collection and Preservation of samples, EPA - 1060; U.S. Environmental Protection Agency (USEPA). www.epa.gov/epaoswer/hazwaste/test /main.htm

[22] Lead Atomic absorption Furnace Technique, EPA Method 7421; U.S. Environmental Protection Agency (USEPA), SW-846 On-Line. www.epa.gov/epaoswer/hazwaste/test/main.htm

[23] Acid Digestion of Aqueous Samples and Extracts for Total metals for the analysis by GFAA Spectroscopy, EPA Method 3020A; U.S. Environmental Protection Agency (USEPA), SW-846 On-Line. www.epa.gov/epaoswer/hazwaste/test/main.htm

[24] Lorenza, R.M., Troast, R., Mostriano, M., Follansbee, M.H. \& Diamond, G.L., Lead intervention and pediatric blood lead levels at hazardous waste sites. Journal of Toxicology and Environmental Health, Part A, (66), pp.871-892, 2003. 